\title{
T-Cell Proliferation of Uncertain Malignant Potential
}

National Cancer Institute

\section{Source}

National Cancer Institute. T-Cell Proliferation of Uncertain Malignant Potential. NCI

Thesaurus. Code C27897.

A T-cell lymphoproliferative disorder with uncertain malignant potential. A representative example is lymphomatoid papulosis. 